\title{
Notes on Wallace's Racer Wallaceophis gujaratensis (Serpentes, Colubrinae): a recently described species endemic to Gujarat, India
}

\author{
RAJU VYAS ${ }^{1}$, DEVVRATSINH MORI ${ }^{2}$, KARTIK UPADHYAY ${ }^{3} \&$ HARSHIL PATEL $^{4 *}$
}

\author{
${ }^{1}$ Sashwat Apartment, BPC-Haveli Road, Nr. Splatter Studio, Alakapuri Vadodara - 390007, Gujarat, India \\ ${ }^{2}$ Natraj cinema, Kharava pole, wadhwan 363030, Gujrat, India \\ ${ }^{3} 1 / 101$ Avni Residence, Near Bansal Super Market, Gotri Vasna Road, Vadodara, Gujarat, India \\ ${ }^{4}$ Department of Biosciences, Veer Narmad South Gujarat University, Surat365007, Gujarat, India \\ Corresponding author e-mail: harshilpatel121@gmail.com
}

$\mathrm{O}_{w}^{\mathrm{b}}$ bservations in 2007 on a snake from Bhavnagar (Gujarat) with two black longitudinal stripes led eventually to naming of a new genus and species, Wallaceophis gujaratensis (Mirza et al., 2016), shown in Figure 1. The genus name honours Alfred Russel Wallace for co-discovering the theory of evolution by natural selection. This species was described on the basis of three specimens all from Gujarat, India (Mirza et al., 2016). This note presents some natural history information and new distribution records from Gujarat, collected subsequent to the description of the species.

Whilst monitoring birds of prey in Surendranagar district, Saurashtra region in the period 2013 to 2015, we detected $W$. gujaratensis in the food samples of Short-toed snake eagle (Circaetus gallicus). The breeding pair of Short-toed eagle under observation offered 23 different species of vertebrates, including amphibians, reptiles, birds and mammals to their hatchlings. Dead snakes of various sizes were offered and in all three years of study W. gujaratensis was included.

We were able to examine five specimens of $W$. gujaratensis from five different localities in Gujarat (Table 1). All five were provided by local rescuers and thoroughly examined. After taking photographs for documentation, the specimens were released back into scrub habitats from near their original rescue sites, except for two voucher specimens deposited in NCBS (National Centre for Biological Science) Museum, Bangalore, India. In addition to these specimens, we received a photograph of a further $W$. gujaratensis from Bayad, Aravalli but the specimen was not available for examination. However, we have included this locality in the updated distribution map of the species (Fig. 2) based on the photograph.

Data on locality, habitat type, scales and body measurements are shown in Table 1. Ventral scales were counted following the method proposed by Dowling (1951) other characters were recorded following Patel et al. (2015). Body measurements were made with string and a ruler to the nearest $\mathrm{mm}$. The number of dorsal scale rows was counted at approximately one head length behind the head, mid-body, and one head length before the vent, respectively. Sub-caudal counts reported here do not include the terminal scute. Values for symmetric head characters are given in right/ left order. Sex was determined by checking the presence of hemipenes, whenever possible.

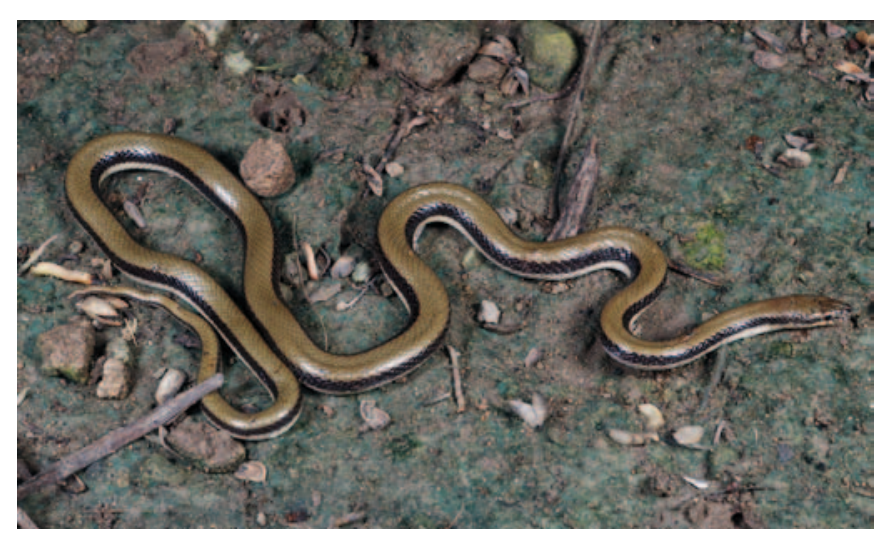

Figure 1. Dorso-lateral aspect of Wallace's Racer (W. gujaratensis) from Madhavpur Ghed, Porbandar District, Gujarat

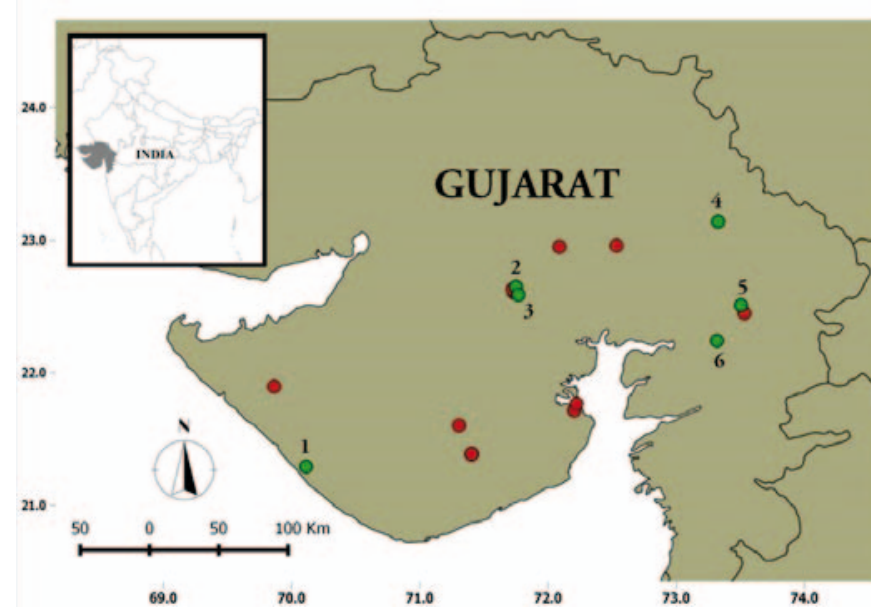

Figure 2. Map showing distribution range of Wallace's Racer (W. gujaratensis). Red circles represent localities reported in literature. Green circles represent new records as follows: 1. Madhavpur Ghed, Porbandar district; 2. Kharwa, Surendranagar district; 3. Wadhwan, Surendranagar distric; t 4. Bayad, Aravalli district; 5. Halol, Panchmahal district; 6. Khatumba, Vadodara district

With one exception, the colour and markings of all five specimens matched those of the species description (Mirza et al., 2016). The exception was that belly marking were not present for the specimens of Halol and Khatumba. Both were large adult females whose ventral belly markings had faded and were totally indistinct (Fig. 3A). But in two 
Table 1. Measurements (cm), scale counts and collection details of Wallace's Racer (W. gujaratensis), Gujarat, India

\begin{tabular}{|c|c|c|c|c|c|}
\hline Specimen No. & 1 (NCBS AQ496) & 2 (NCBS AQ497) & 3 & 4 & 5 \\
\hline Locality & $\begin{array}{c}\text { Halol, } \\
\text { Panchmahal District }\end{array}$ & $\begin{array}{c}\text { Wadhwan, } \\
\text { Surendranagar District }\end{array}$ & $\begin{array}{l}\text { Khatumba, Waghodiya } \\
\text { Road, Vadodara District }\end{array}$ & $\begin{array}{l}\text { Kharva, Wadhwan, } \\
\text { Surendranagar District }\end{array}$ & $\begin{array}{l}\text { Madhavpur Ghed, } \\
\text { Porbandar District }\end{array}$ \\
\hline Geo-coordinates & $\begin{array}{l}22^{\circ} 29^{\prime} 48.88^{\prime \prime} \mathrm{N} \\
73^{\circ} 28^{\prime} 20.59^{\prime \prime} \mathrm{E}\end{array}$ & $\begin{array}{l}22^{\circ} 42^{\prime} 23.02^{\prime \prime N} \\
71^{\circ} 40^{\prime} 25.28^{\prime \prime} \mathrm{E}\end{array}$ & $\begin{array}{l}22^{\circ} 17^{\prime} 9.12^{\prime \prime N} \\
73^{\circ} 15^{\prime} 25.69^{\prime \prime} \mathrm{E}\end{array}$ & $\begin{array}{l}22^{\circ} 38^{\prime} 38.21^{\prime \prime} \mathrm{N} \\
71^{\circ} 41^{\prime} 45.51^{\prime \prime} \mathrm{E}\end{array}$ & $\begin{array}{l}21^{\circ} 17^{\prime} 57.44^{\prime \prime} \mathrm{N} ; \\
70^{\circ} 11^{\prime} 30.50^{\prime \prime} \mathrm{E}\end{array}$ \\
\hline Altitude (meters) & 102 & 51 & 35 & 54 & 9 \\
\hline Date of rescue & 11 March 2013 & 15 March 2016 & 15 February 2018 & 20 September 2018 & 7 October 2018 \\
\hline $\begin{array}{l}\text { Habitat / } \\
\text { vegetation }\end{array}$ & $\begin{array}{l}\text { Industrial Area / } \\
\text { Cultivated garden }\end{array}$ & House / No vegetation & $\begin{array}{c}\text { New Urban Settlement / } \\
\text { Agricultural }\end{array}$ & $\begin{array}{l}\text { New Human Settlement } \\
\text { / Scrubland }\end{array}$ & $\begin{array}{c}\text { Rural / } \\
\text { Agricultural }\end{array}$ \\
\hline TL & 93.0 & 68.3 & 81.0 & 14.5 & 45.5 \\
\hline SVL & 82.0 & 60.0 & 70.5 & 9.0 & 37.8 \\
\hline Tal & 11.0 & 8.30 & 10.5 & 5.5 & 7.7 \\
\hline $\begin{array}{l}\text { Dorsal scale row } \\
\text { Anterior: middle; } \\
\text { posterior }\end{array}$ & $25: 23: 17$ & $24: 23: 21$ & $25: 23: 17$ & $25: 23: 17$ & $25: 23: 18$ \\
\hline Ventrals & 233 & 239 & 231 & 220 & 214 \\
\hline Anal & Single & Single & Single & Single & Single \\
\hline $\begin{array}{l}\text { Sub-caudals } \\
\text { (divided) }\end{array}$ & 52 & 54 & 59 & 52 & - \\
\hline Supra-labials & $8 / 8$ (4th ,5th touch the eye) & $\begin{array}{l}8 / 8 \text { ( } 4 \text { th , } 5 \text { th touch the } \\
\text { eye) }\end{array}$ & $\begin{array}{l}8 / 8 \text { ( } 4 \text { th , } 5 \text { th touch the } \\
\text { eye) }\end{array}$ & $\begin{array}{c}8 / 8 \text { (4th ,5th touch the } \\
\text { eye) }\end{array}$ & $\begin{array}{c}8 / 8 \text { (4th ,5th touch the } \\
\text { eye) }\end{array}$ \\
\hline Infra-labials & 10/11 (6th biggest) & $10 / 10$ (6th biggest) & 9 (6th biggest) & 9 (6th biggest) & - \\
\hline Loreal & Single & Single & Single & Single & Single \\
\hline Pre-ocular & 1 & 1 & 1 & 1 & 1 \\
\hline Post-ocular & 2 & 2 & 2 & 2 & 2 \\
\hline Temporal & $1+2$ & $1+2$ & $1+2$ & $1+2$ & $1+2$ \\
\hline Sex & Female & Not determined & Female & Not determined & Not determined \\
\hline
\end{tabular}

smaller specimens collected from Amareli and Kharva; the ventral markings were distinct (see Fig. 3B of Mirza et al., 2016). It would appear that the belly markings fade with age. The snout to vent body length (SVL) of the species was documented to range from 25.3 to $93.0 \mathrm{~cm}(\mathrm{n}=9$ ) (Mirza et al., 2016). In our collection the shortest SVL was $14.5 \mathrm{~cm}$. This was from a specimen probably only one month old found in September. This suggests that it hatched from the egg in August which coincides with the typical July to September wet season breeding of snakes in India (Smith, 1943).

Here, we add further precise colour markings of body scale rows along with the size of body scales, not mentioned in Mirza et al. (2016); lateral most two scale rows being large and light yellow towards each side (2 rows); dorso-lateral six scale rows smaller than the lateral most scales but larger than the mid-dorsal scale rows with dark brown colour, upper and lower most scales of these rows are partially coloured (half portion of the scale row is dark brown and other half is wheat coloured) on each side ( $1+4+1$ rows); mid-dorsal scale rows smaller than the dorso-laterals and lateral scale rows with light cream or wheat colour ( 9 rows). The total body scale rows 25 at mid-body part $(2+6+9+6+2=25)$, mid-dorsal rows are reduced towards the anterior body part (as 24 rows) and same as in posterior body part (as 21 or 17 rows).

The new locality records show that the species is actually quite widespread in Gujarat and can be found close to human habitation. Despite being a reasonably common snake species of Saurashtra and Central Gujarat, the species

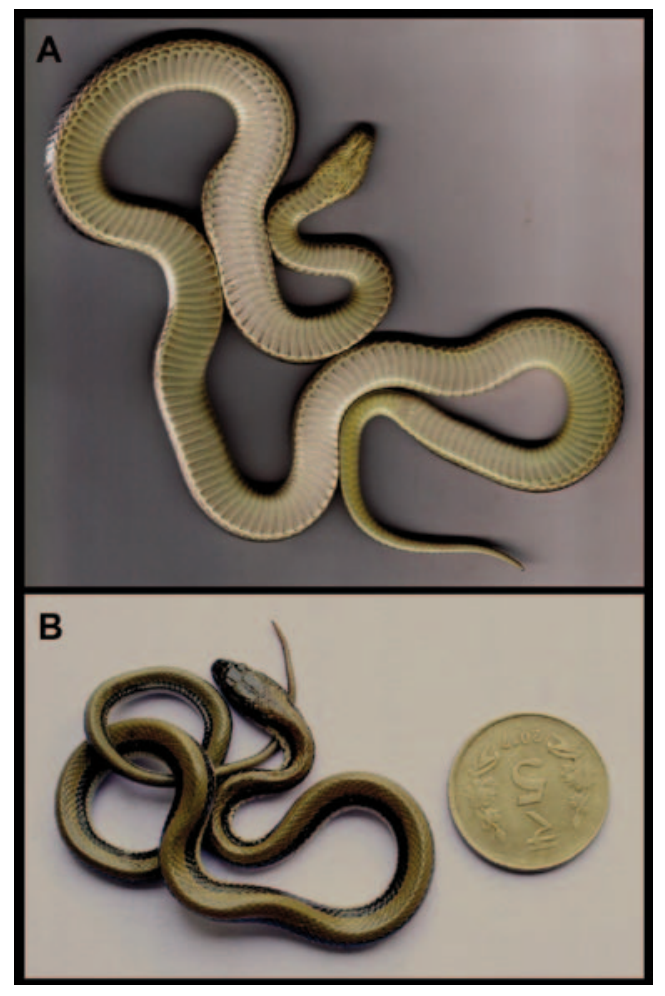

Figure 3. A. Large adult Wallace's Racer (W. gujaratensis) from Kalol, Panchmahal District, showing each ventral scale with indistinct brown spot on each anterior corner $\mathbf{B}$. The dorsal aspect of smallest ever recorded specimen of Wallace's Racer (W. gujaratensis) from Kharva, Surendranagar District, Gujarat 
was only described very recently. It is possible that earlier explorers might have misidentified $W$. gujaratensis as Coelognathus helena. However, Gujarat largely remains unexplored herpetologically so that it is also possible that this species simply evaded the attention of earlier workers.

\section{ACKNOWLEDGMENTS}

The authors thank the State Forest Department, Gujarat, especially the Conservator of Forest and Dy. Conservator of Forest (wildlife), Surendranagar and Vadodara for allowing examination of the rescued specimens. We thank Pranav Vaghashiya and Bhautik Dudhatra for sharing their photographs and observations from Madhavpur Ghed. Also, we thank Varad Giri for his help in specimen deposition at the museum of National Center for Biological Science, Bangalore, India. Thanks to Khushboo Vyas for proof-reading the English draft and other language improvements. We wish to credit Pranav Vaghashiya for the photograph in Figure 1.

\section{REFERENCES}

Dowling, H.G. (1951). A proposed standard system of counting ventrals in snakes. British Journal of Herpetology 1: 9799.

Mirza, Z.A., Vyas, R., Patel, H., Maheta, J. \& Sanap, R.V. (2016). A new Miocene-Divergent lineage of old world racer snake from India. PLOS ONE 11: 1-17. e0148380. doi:10.1371/ journal.pone.0483380.

Patel, H., Vyas, R. \& Tank, S.K. (2015). On the distribution, taxonomy and natural history of the Indian smooth snake, Coronella brachyura (Günther, 1866). Amphibian \& Reptile Conservation 9: 120-125.

Smith, M.A. (1943). The Fauna of British India, including Ceylon and Burma. Reptilia and Amphibia Vol. III. Serpentes. Taylor and Francis, London. 583 pp.

Accepted: 13 May 2019 